\title{
The Lasting Effects of Colonial Violence: How Water Becomes Linked to Violence in Maryse Condé and Simone Schwarz Bart
}

\author{
Felisa Vergara REYNOLDS
}

fter reading certain works, one is sometimes left with the notion
that what may have at first appeared to be a backdrop for a greater
story turns out to be the story itself. This can certainly be said for I, Tituba, Black Witch of Salem and The Bridge of Beyond, for I have felt compelled to examine the manner in which certain images, poetic images if you will, seem to have emerged from the background to occupy center stage. Within the two novels there exists a strikingly similar pattern of acts and images. How does one account for this phenomenon? Perhaps, it is that this imagery is a by-product of the underlying relationship between the insularity of Guadeloupe and the female characters created by Condé and Schwarz-Bart. Accordingly, what will be conducted is a sort of phenomenological study - that is a "phenomenology of the imagination. By this should be understood a study of the phenomenon of the poetic image when it emerges into the consciousness as a direct product of the heart, soul and being [. . .]" (Bachelard, Poetics xviii). In these two novels, I will specifically focus on the imagery that seems to be the product of a certain geographical violence. As such, it will become apparent that a link exists between the historical violence of the island of Guadeloupe and certain narrative leitmotivs, such as water (particularly the ocean), female characters (particularly the mother) and ultimately death. 
The study begins with "the consideration of the onset of the image" (xix). A priori, I imagine a relationship between the images and water that is nefarious from its inception. This pernicious relationship is certainly contrary to the one that is generally presented between woman and water. Customarily, though questionably so, we are used to seeing woman and water - and even more often the mother figure and the ocean represented as givers of life, protective and nurturing. In French the homonym is particularly striking as la mer/la mère (mother/ocean). Such definitions of this nurturing mother/ocean can be found ad-infinitum in literature. So frequent is this representation that it appears as a constant throughout genres and across centuries. To cite but a few of these examples, from Bachelard we draw "The Sea is for all men one of the greatest and most constant maternal symbols" (Water 115). Or we can go further back in history to read that in Greek mythology "Creation has often been imagined as the marriage of fire and water; it is warmth and moisture that give rise to living things; the Sun is the husband of the Sea; the Sun, fire, are male divinities; and the Sea is one of the most nearly universal of maternal symbols" (Beauvoir 144). To quote Irigaray, from Marine lover of Friedrich Nietzsche, she would perhaps describe the aforementioned conceptions of nature and of water as "A disgrace to the whole theater of representation. Irreducible contortion of a nature mimicking the residue of a poorly staged mimicry" (78). "When you come right down to it, it's phony, false, fake, deceptive, etc. And undisguisedly so" (Ibid).

What Bachelard et al. overlook is that throughout history there has existed another type of water, another aquatic archetype, one having nothing to do with nurturing. This other archetype is destructive. It is that of "the Mare Tenebrarum, dreaded by navigators of old; it is night in the entrails of the earth. Man is frightened of this night, the reverse of fecundity, which threatens to swallow him up" (Beauvoir 147, emphasis added). This Mare Tenebrarum stands in powerful contrast to the aforementioned maternal waters. It is with this new aquatic archetype in mind that I approach the works of Condé and Schwarz-Bart, because in the textual world created by these two authors, the waters will indeed epitomize the reverse of fecundity. In I, Tituba, Black Witch of Salem and in The Bridge of Beyond the water is dangerous and carries death in its swells. Victor Hugo in Les Travailleurs describes this violent water as "the Ocean's anger" that "grumbles and roars. It is given all the metaphors of fury, all the animal symbols of fury and rage [...] Its foam resembles the saliva of a leviathan, the water is full of claws" (qtd. in Bachelard, Water 
171). Hugo's emphasis, much like that of Condé and Schwarz-Bart, is on the water of the oceans, which seems to be responsible for the miseries that afflict the central characters.

I propose that these brutal waters are a projection by Condé and Schwarz-Bart of the violent past that haunts their native Guadeloupe. This violent past is inescapable, for we know that Guadeloupe still bears the scars of suffering caused by the cultivation of the sugarcane. For two hundred years death and misery were brought upon this island by a succession of colonizers, which resulted in the decimation and permanent displacement of the indigenous Arawak and Carib population. Furthermore, throughout its history Guadeloupe has seen over twenty-five million men and women imported from Africa, toil and die in its sugarcane fields. ${ }^{1}$ It is this violence that is brought forth from the waters and into the characters of the two novels. The violent waters in the text also reflect the relationship between the female characters and their mothers - bringing us back the homonym, la mer/la mère. In addition to being violent, the water is ambivalent, even a paradox, for the very same image simultaneously gives and takes life (Helm 2). To quote Bachelard: "At the level of the poetic image, the duality of the subject and object is iridescent, shimmering, unceasingly active [...]" (Poetics xix). Hence, the image of the ocean and that of the feminine characters - particularly those of the mothers - mutually reflect each other in I, Tituba, Black Witch of Salem and The Bridge of Beyond. In fact, one can say that Condé and SchwarzBart commit literary matricide in order to valorize a new mother, a new archetype that feeds on a violent past and on violent waters.

The first example of this new mother/water couple comes from Condé's novel, I, Tituba, Black Witch of Salem. From the onset, it is important to note that although Tituba's story takes place in Barbados, as Scarboro points out, "the historical Tituba was actually Barbadian [. . .] Condé uses Barbados instead of Guadeloupe as the Caribbean locale, but she infers similar circumstances from the history of slavery common to the region" (qtd. in Condé 187).

From the beginning of her novel, Condé simultaneously brings us face to face with the poetic images of violence, water, and motherhood. Tituba opens the narrative by recounting how her mother Abena "was raped by an English sailor on the deck of Christ the King one day in the year " $16^{* *}$ " while the ship was sailing for Barbados. I was born from this act of aggression. From this act of hatred and contempt" (Condé 3). These initial images are of utmost importance, and heavily charged with symbolism. Simultaneously we are in the realm of water, violence and 
motherhood, all at once. On a phenomenological level the image of the rape and conception on water leads us to imagine that the water is somehow complicit in this act of violence - one that creates a mother who identifies more with hatred and aggression than with nurturing and affection.

The rape on the water resounds like an echo "and it will be hard to know at what depth [it] will reverberate" for "the poetic image has an entity and dynamism of its own" (Bachelard, Poetics xvi). The echo rings hollow, for Abena will develop no motherly feelings of affection towards her daughter. Tituba recounts: "When did I discover that my mother did not love me? Perhaps when I was five or six years old [...] whenever I used to cuddle up to her as children are wont to do, she would inevitably push me away" (Condé 6). It is thus unsurprising that Abena would reject her daughter, given the circumstances surrounding her conception. Condé rejects the possibility of a maternal bond between Abena and Tituba by suppressing all "philotès or tenderness" associated with motherhood. According to Irigaray, the rejection of philotès "re-establishes a sort of primitive chaos" that would explain the refusal or rupture of the mother/ daughter bond between Abena and Tituba (Thinking 95). Furthermore, in this chaos reigns a violence that permits Condé to weave into her novel a systematic destruction via water.

The juxtaposition of water and violence is the topos that will carry us across I, Tituba, Black Witch of Salem. From this point forth the presence of water will signal devastation to our protagonist. If the rape was the initial violence, then the resulting violence is seen when Tituba meets her first love, John Indian. The now-familiar leitmotiv lets the reader know that this relationship is doomed, and will have devastating consequences. The pronouncement of misery comes from fateful words uttered by John Indian: "I belong to Goodwife Susanna Endicott who lives over there in Carlisle Bay.' He pointed to the sea glistening in the distance" (Condé 14, emphasis added). Tituba's demise, which had begun the day her mother was raped, accelerates from the moment the waters surrounding Carlisle Bay are mentioned. Even Tituba seems keenly aware of the danger that lies in the water, as she understands in an instant that her downfall is now "like a river that can never be fully diverted from its course" (15). Soon Tituba finds herself "dragged off to the other side of the water" where she becomes a slave under Susanna Endicott, like her lover John Indian (Ibid.). As Tituba becomes a slave, Susanna Endicott takes on the role of substitute mother. And as with her birth mother, the encounter with Susanna is very negative and again the presence of water is markedly felt. In recounting this first meeting, Tituba says, "I could read all the 
aversion she had for me in her eyes, which were the color of sea water. She stared at me as if I were an object of disgust" (21). Just as her mother was never able to love her, it becomes clear that her new mistress will never love her either. Furthermore, the relationship between Tituba and Susanna will be so contentious that the water becomes almost palpable. In one of her last encounters with Susanna, Tituba describes her mistress' eyes as "the color of stormy seas" (Ibid.). The stormy seas in the eyes of the mistress foretell what we know is to come.

Shortly thereafter Tituba finds herself sold to another master, the tyrannical pastor Samuel Parris. And just as Susanna dragged Tituba to the other side of the water, so will Samuel, only this time all the way to America. On the voyage to America, Tituba will suffer the worst indignities to date. The waters will once again conspire to harm her. Shortly after boarding the ship Blessing, we watch as her new master makes Tituba "kneel on the deck [...] among the ropes and barrels. The jeering sailors watched as he poured a trickle of icy water on [her] forehead" (36). As she recalls this impromptu baptism Tituba shivers and notes that around her "the sea was a bright blue" (Ibid.). It is as if Condé is continually striving to bring the water's complicity to the attention of the reader. This complicity continues to manifest itself even after Tituba finds herself in America. In fact Condé doesn't miss another opportunity to commit matricide, for shortly thereafter, she has Tituba attend a public hanging reminiscent of her own mother's hanging twenty years earlier. Not so coincidentally, it is after she witnesses this hanging that she discovers she is pregnant. But, like her own mother, Tituba does not feel she is meant to be a mother. In the face of the violence that accompanies the hanging she states: "I realized I was pregnant and I decided to kill the child" (49). Once again, violence begets violence as Tituba perpetuates the cycle originated the day of her mother's rape. Again, we see that the lack of philotès or tenderness results in "the need to destroy [. . .] life" (Irigaray, Thinking 97). To destroy the life growing inside her, Tituba drinks a potion, which causes her to abort the fetus. At the death of her unborn child, a familiar leitmotiv returns as she sings a song she entitles Lament for my lost child:

The moonstone dropped into the water,

Into the waters of the river,

And my fingers couldn't reach it,

Woe is me!

The moonstone has fallen.

Sitting on a rock on the riverbank 
I wept and I lamented.

Oh, softly shining stone,

Glimmering at the bottom of the water.

The hunter passed that way

With his bow and arrows.

"Why are you crying, my lovely one?"

"I'm crying because my moonstone

Lies at the bottom of the water."

"If it is but that, my lovely,

I will help you"

But the hunter dived and was drowned. (55)

What I find most remarkable about this song is the presence of diverse poetic images linked to both mother and water. True to the poetic image, that which is described by Tituba seems to come from her "consciousness as a direct product of the heart, soul and being" (Bachelard, Poetics xviii). Tituba laments that her moonstone has fallen to the bottom of the river. The moonstone is certainly a metaphor for her child, and Tituba weeps for the loss. This song would seem a paroxysm, an ultimate culmination of the link among violence, water and motherhood. In Lament for my lost child, the water not only takes her child, but also sparkles with the reflection of the murderous mother - Tituba. The culmination of these symbols once more serves as a premonition of the most important death of all Tituba's. In the end the symbols come full circle with Tituba hanged just as her mother.

In a fashion quite similar to Condé, Schwarz-Bart, in The Bridge of Beyond, creates a world in which, once again feminine images are closely linked to an aquatic presence. Moreover, it would also appear that Schwarz-Bart is equally conscious of the existence of the 'bad water' and the 'bad mother.' The bad mother in Schwartz-Bart is the one who will rebel against tradition and whose female characters are but a reflection of the surrounding waters. The mutual reflection is perhaps more subtle with Schwarz-Bart, but yet ever so present as her characters navigate in the realm of waters that cause misery and death. In this case the initial complicity of the waters lies not in rape, but in the treacherous middle passage. It is the echo of this pain and violence that resounds in the female characters, especially the mother.

Schwarz-Bart gets right to the heart of the matter, much like Condé, by presenting early on in the novel the feminine character that will serve as catalyst for the narrative. For Schwarz-Bart, the duty falls to a matriarch named Minerva. This name is quite remarkable, for Minerva in Roman 
mythology (or Pallas Athena as she was once called) was born of Zeus alone. (Hamilton) "No mother bore her. Full-grown and in full armor she sprang from his head. In the earliest account of her, the Iliad, she is a fierce and ruthless battle-goddess [. . .] She was Zeus' favorite child. $\mathrm{He}$ trusted her to carry the awful aegis, his buckler, and his devastating weapon, the thunderbolt" (Hamilton 29). She was a fierce combatant, a domain normally reserved for gods and men, not goddesses, and certainly not women. This coincidence, or perhaps this precise calculation by Schwarz-Bart, further serves to underline the relationship between violence, water and women. In Schwarz-Bart, as with Condé, water is the flashing warning light that signals danger and violence to come.

To illustrate this point we need only turn to Minerva and her pregnancy as described in The Bridge of Beyond, where Minerva states that her pregnancy is the result of a relationship with a man who has come via the water "from the Dominican Republic, a black man who disappeared at the mere mention of fatherhood" (Schwarz-Bart 4). Once more, the sea brings misfortune in its swell, making it painfully clear that this child has been conceived under the gaze of nefarious water. Thus, Minerva's bastard daughter, Toussine, is born under a gaze that will follow her. After an uneventful childhood, Toussine grows up only to fall in love with Jeremiah, a fisherman, whose friends would tease by saying, "When Jeremiah falls in love it will be with a mermaid" (6). Within this context, the appearance of a mermaid as love object is an inspired choice, for these mythical creatures lay in wait of sailors and lured them to their death with their chants. The coming together of these very specific poetic images can only signal bad things to come for the union of Jeremiah and Toussine. The misery reveals itself a few years later, as one of their daughters, Meranee, is tragically killed. With her daughter's death, Toussine falls into a deep depression which Schwartz-Bart describes thusly: "The leaf that falls into the pond does not rot the same day, and Toussine's sorrow only grew worse with time, fulfilling all the gloomy predictions"(19). The leaf rotting in the pond is a powerful omen indeed. Toussine eventually recovers, giving birth to Victory only to later abandon her and her sister Eloisine: "She left them to steer the course of their lives under their own sail" (21). Toussine's two daughters find themselves in a familiar situation; they are left without a mother. And in a narrative twist that is rather surprising, Schwarz-Bart decides to pursue the story of only one of the daughters - Victory, leaving us to wonder as to the fate of Toussine's other daughter, Eloisine. It seems that Eloisine is doubly abandoned, once by her mother and the second time by her creator - Simone SchwarzBart. 
As befits the pattern, Victory, like Toussine and Minerva before her, will not be able to fulfill her maternal role to the fullest, as she will also be cursed by the waters that surround her. After two uneventful pregnancies, with Regina and Telumee, she suffers the stillbirth of her only son after "she slipped on a stone" while doing laundry by the river. (26) The river is in this case the culprit which prevents Victory from assuming the role of motherhood to the all-important male child which would have presumably helped her fulfill the role of 'good mother' as well. After this tragedy, Victory would wander the streets saying: "People see me in the street, but who can know this belly has carried a man [...] who can know that, eh?" (Ibid.). This tragedy is compounded by the subsequent murder of Victory's lover, Angebert, because of a dispute over stolen crayfish (31-2). A couple of years after the death of Angebert, Victory meets HautColbi who is described as a man "who moved as if his natural element was water - it was as though he was swimming" (37). This union will have devastating consequences for Telumee, for after moving in together, Victory and Haut-Colbi decide to ship her off to live with her grandmother. As for the other daughter, Regina, she suffers the same narrative fate as Eloisine, disappearing almost totally from the novel. Once, again, the water betrays Telumee as Victory and Haut-Colbi decide to sail away to another island. Reversing the trip once made by Victory's Grandfather, she lets the waters lead her away from her children to the Dominican Republic. The cycle repeats itself after one of the daughters, Telumee, grows up and begins a relationship with a man named Elie. Once again this is a romance born in and out of water, Telumee and Elie fall in love while bathing in the depths of the "Blue Basin" (67). The danger in this union is foretold not only by the water, but also by her grandmother who warns Elie "If you are shipwrecked, man, she will go down with you" (116). As forewarned, the relationship takes a turn for the worse and Elie announces to Telumee: "what I've always feared is happening. We no longer live on solid earth [...] we're out at sea amid the currents, and what I wonder is whether I'm going to drown outright" (141). Shortly thereafter, Elie begins to beat Telumee "unmercifully without saying a word" (144). This relationship will see Telumee reduced from human to marine life, to "a crab without claws" and a "crab without a head" (160-1). After some time, Telumee recovers from the disastrous relationship with Elie and falls in love with a good man, Amboise, only to have the waters punish her again. Amboise is killed by a stream of boiling water and steam. As a result, Telumee will never become a mother and will spend the rest of her life in solitude surrounded by the waters that cursed her. 
In the end, one must admit the inherent difficulty in ascertaining whether a conscious or unconscious choice was made in the use of certain leitmotivs by Condé and Schwarz-Bart. Speculation not withstanding, the violent past of Guadeloupe is certainly a palpable presence in I, Tituba, Black Witch of Salem and in The Bridge of Beyond. It seems as though the violence of the past has lingered for so long in the air of Guadeloupe, that much like an echo it has reverberated into and through the consciousness of these two writers. All the while, the echo has remained violent, and the end result is the careful manipulation by Condé and Schwarz-Bart of certain poetic images that succeed at upending some very powerful archetypes. Bachelard wrote, "the poetic image has an entity and dynamism of its own" (Poetics xvi). Truly, certain poetic images appear to have an entity and dynamism of their own in $I$, Tituba, Black Witch of Salem as well as The Bridge of Beyond.

Notes

1. Information on the violent past of Guadeloupe was obtained from http://www.guadeloupe-panorama.com/histoire2.htm

\section{Works Cited}

Bachelard, Gaston. The Poetics of Space. Boston: Beacon Press, 1994. —, Water and Dreams. Dallas: The Pegasus Foundation, 1999.

Beauvoir, Simone de. The Second Sex. New York: Knopf, 1993.

Condé, Maryse. I, Tituba, Black Witch of Salem. New York: Ballantine Books, 1994.

Hamilton, Edith. Mythology. Timeless Tales of Gods and Heroes. New York: Mentor, 1942.

Helm, Yolande. L'Eau. Source d'une écriture dans les littératures francophones. New York: Peter Lang, 1995.

Irigaray, Luce. Marine Lover of Friedrich Nietzsche. New York: Columbia University Press, 1991.

-, Thinking the difference. For a peaceful revolution. New York: Routledge, 1994.

Schwarz-Bart, Simone. The Bridge of Beyond. New York: Atheneum, 1974. 